\title{
Treatable traits: toward precision medicine of chronic airway diseases
}

\author{
Alvar Agusti ${ }^{1}$, Elisabeth Bel $^{2}$, Mike Thomas $^{3}$, Claus Vogelmeier $^{4}$, \\ Guy Brusselle ${ }^{5,6}$, Stephen Holgate ${ }^{7}$, Marc Humbert ${ }^{8}$, Paul Jones ${ }^{9}$, \\ Peter G. Gibson ${ }^{10}$, Jørgen Vestbo ${ }^{11}$, Richard Beasley ${ }^{12}$ and lan D. Pavord ${ }^{13}$
}

\begin{abstract}
Affiliations: ${ }^{1}$ Respiratory Institute, Hospital Clinic, IDIBAPS, University of Barcelona, Barcelona and CIBER Enfermedades Respiratorias (CIBERES), Spain. ${ }^{2}$ Dept of Respiratory Medicine, Academic Medical Centre, University of Amsterdam, Amsterdam, The Netherlands. ${ }^{3}$ Primary Care and Population Sciences, University of Southampton, Southampton, UK. ${ }^{4}$ Dept of Medicine, Pulmonary and Critical Care Medicine, University Medical Center Giessen and Marburg, Philipps-Universität Marburg, and Member of the German Center for Lung Research (DZL), Germany. ${ }^{5}$ Dept of Respiratory Medicine, Ghent University Hospital, Ghent, Belgium. ${ }^{6}$ Depts of Epidemiology and Respiratory Medicine, Erasmus Medical Center, Rotterdam, The Netherlands. ${ }^{7}$ Clinical and Experimental Sciences, Faculty of Medicine, University of Southampton, Southampton General Hospital, Southampton, UK. ${ }^{8}$ Université Paris-Sud; Service de Pneumologie, Hôpital Bicêtre (Assistance PubliqueHôpitaux de Paris); INSERM UMR_S 999, Le Kremlin-Bicêtre, France. ${ }^{9}$ St George's University of London, London, UK. ${ }^{10}$ Dept of Respiratory and Sleep Medicine, John Hunter Hospital, Hunter Medical Research Institute, and Priority Research Centre for Asthma and Respiratory Disease, The University of Newcastle, NSW, Australia. ${ }^{11}$ Centre for Respiratory Medicine and Allergy, Manchester Academic Health Science Centre, University Hospital South Manchester NHS Foundation Trust, Manchester, UK. ${ }^{12}$ Medical Research Institute of New Zealand, Wellington, New Zealand. ${ }^{13}$ Respiratory Medicine Unit, NDM Research Building, Nuffield Dept of Medicine, University of Oxford, Oxford, UK.
\end{abstract}

Correspondence: Alvar Agusti, Respiratory Institute, Hospital Clinic, Villarroel 170, 08036 Barcelona, Spain. E-mail: Alvar.Agustidaclinic.ub.es

ABSTRACT Asthma and chronic obstructive pulmonary disease (COPD) are two prevalent chronic airway diseases that have a high personal and social impact. They likely represent a continuum of different diseases that may share biological mechanisms (i.e. endotypes), and present similar clinical, functional, imaging and/or biological features that can be observed (i.e. phenotypes) which require individualised treatment. Precision medicine is defined as "treatments targeted to the needs of individual patients on the basis of genetic, biomarker, phenotypic, or psychosocial characteristics that distinguish a given patient from other patients with similar clinical presentations". In this Perspective, we propose a precision medicine strategy for chronic airway diseases in general, and asthma and COPD in particular.

@ERSpublications

A discussion of the concept of "treatable traits" as a way towards precision medicine of chronic airway diseases http://ow.ly/UbJAm

For editorial comment see Eur Respir J 2016; 47: 359-361 [DOI: 10.1183/13993003.01930-2015].

Received: Aug 152015 | Accepted after revision: Oct 272015

Support statement: A. Agusti is supported by Instituto de Salud Carlos III (PI12/01117), Recercaixa-2012 (AA084096), SEPAR (PI065/2013, PI192/2012) and FUCAP 2012; M. Thomas is supported by the NIHR Southampton Biomedical Research Unit, NIHR Wessex CLAHRC; M. Humbert is supported by Université Paris-Sud, INSERM and AP-HP (DHU Thorax Innovation); R. Beasley is supported by HRC NZ IRO grant.

Conflict of interest: Disclosures can be found alongside the online version of this article at erj.ersjournals.com

Copyright OERS 2016 
I cannot say whether things will get better if we change; what I can say is they must change if they are to get better.

G.C. Lichtenberg (quoted in [1])

\section{Introduction}

During the State of the Union Address on January 20, 2015, President Barack Obama launched a research initiative aimed at accelerating progress toward a new era of "precision medicine" [2]. Precision medicine is defined as "treatments targeted to the needs of individual patients on the basis of genetic, biomarker, phenotypic, or psychosocial characteristics that distinguish a given patient from other patients with similar clinical presentations" [3]. The final objective of precision medicine is to "improve clinical outcomes for individual patients while minimizing unnecessary side effects for those less likely to respond to a given treatment" [3]. The concept of precision medicine, however, is not entirely novel in medical practice since it has always been the physician's task to manage patients individually towards better outcomes [4]. The novelty is that modern medicine is allowing this at a higher level of biological and clinical precision and integration since new measurements have become available and systems approaches allow a new level of integration of clinical and biological knowledge [4-7].

Asthma and chronic obstructive pulmonary disease (COPD) are two prevalent chronic airway diseases that carry a high personal and social toll $[8,9]$. Both are ideally suited for precision medicine because they likely represent a continuum of different diseases that may share biological mechanisms (often referred to as "endotypes") and present similar clinical features (often referred to as "phenotypes") that require "individualised" treatment $[1,10-12]$. For the discussion that follows, it is important to define precisely these two terms. A "phenotype" reflects "what can be observed", including clinical, functional, imaging and/or biological features, and it depends entirely on the specific assessment performed (the so-called "eye of the beholder") [13]. By contrast, the term "endotype" refers to the cellular and molecular pathway(s) involved in the pathogenesis of the disease [14]. Hence, just considering molecular measurements does not address endotypes, unless the critical causal role of the molecular pathway has been established [14]. According to this latter definition, so far only few (if any) endotypes have been identified in airway disease that have therapeutic implications [11, 14]. In this setting, phenotypes can be used for hypothesis generation and probabilistic prediction of treatment outcomes, whereas endotypes are the result of hypothesis testing, being of course also highly suitable for treatment choices.

In the 19th and 20th centuries, a number of different diagnostic "labels" related to airway disease were introduced with the goal of providing an optimal level of precision medicine $[15,16]$. However, in the 21 st century the limitations of the umbrella terms asthma and COPD, and the assumptions that are made when these terms are applied, are increasingly apparent. Here, we propose a precision medicine strategy for chronic airway diseases in general, and asthma and COPD in particular, that is based on the presence of what we propose to call "treatable traits".

\section{Precision medicine of chronic airway diseases: why?}

Both asthma [8] and COPD [9] are "complex" and "heterogeneous". In this setting, "complex" means that they have several components with nonlinear dynamic interactions, whereas "heterogeneous" indicates that not all of these components are present in all patients or, in a given patient, at all time points [17]. This dynamic complexity and heterogeneity explains and justifies the need for a precision medicine approach aimed at improving their assessment, treatment and outcomes $[4,18]$.

The following factors add urgency to this approach and suggest to us that it is timely. 1) The improvements seen in the 1990s in some key outcomes have slowed down despite increased expenditure on treatments. For instance, hospitalisation rates in asthma, which dropped dramatically in the latter part of the last century, have failed to do so since [19] and COPD hospital admission rates continue to increase [9]. Surveys of asthma control consistently show that the majority of patients still exhibit significant symptoms and quality-of-life impairment [20], and exacerbation rates are not falling [21]. 2) We have seen progress in the development of "biomarkers" that can facilitate the implementation of precision medicine in airway diseases. For instance, there exist several reliable markers of eosinophilic airway inflammation which may provide a better perspective on risk and the likely response to treatment with corticosteroids than traditional physiological measures [22-24]. These biomarkers have the additional benefit of being easy to measure, making them ideal for use, even in nonspecialist practice. There is increasing evidence that the use of such biomarkers results in more effective and economical use of currently available treatments [25-28], as well as novel targeted treatments, often biological [29-32]. 3) Progress in new drug discovery has been slower in airway diseases than other specialty areas $[33,34]$. Although several explanations are possible, the most important factors are outmoded disease concepts and poor targeting of treatment [33]. In support of this, progress has been seen when applying the sort of stratified approach we advocate [35-38]. 
Limitations of current diagnostic labels: one size does not fit all

The current classification of human diseases (i.e. the "diagnostic labels" we use in everyday practice) was established in the later part of the 19th century by Sir William Osler on the basis of the principal organ system in which symptoms and signs manifest with some physiological, anatomical and histopathology correlates $[1,39]$. This "Oslerian paradigm" has been the basis of medical teaching and practice for over 100 years, but with the advancement of technology it is now beginning to show its age. There is a growing realisation that the current diagnostic labels are often based upon (sometimes) outdated pathological analyses [40] so that they over-generalise patho-phenotypes, do not take into account susceptibility states or pre-clinical disease manifestations and cannot be used to individualise disease diagnosis or therapy based upon disease-related causal molecular pathways [1,39]. Thus, after the complete sequencing of the human genome [41], in the post-genomic era human diseases will need to be re-classified bottom-up, linking causal molecular pathways (i.e. endotypes) to disease phenotypes (i.e. from molecules to symptoms) $[4,42]$, in contrast to the classical top-bottom approach (i.e. from symptoms to mechanisms) as embraced by Osler $[1,4,12,39]$.

The current management of airway diseases is based on "Oslerian diagnostic labels" (asthma, COPD, others) that do not consider novel genetic, molecular or imaging information $[1,4,5,11,17]$. This approach may be valid for the "stereotypical" patients, but it may be of much less clear value in "intermediate" (and frequent) cases, including adult-onset "asthma", asthmatics with "fixed" airflow limitation, smoking asthmatics or COPD patients with significant airflow reversibility (so-called asthmaCOPD overlap syndrome) $[10,12]$. Furthermore, the pattern of airway inflammation even in classical cases may not be as distinct as has been assumed [43], and both diseases share risk factors which include the genetic background of the individual and family $[11,44]$ and environmental exposures that modulate maximally attained lung function in early adult life $[45,46]$.

Failure to recognise the complexity of airway diseases is clinically relevant for a number of reasons. 1) It can lead to sub-optimal management because diseases with different endotypes may require different therapeutic strategies (i.e. precision medicine) $[1,4,11]$. So far, recommendations for asthma and COPD treatments are based on group mean data from populations that include groups with different phenotypic or endotypic characteristics, which may fail to encompass differences in efficacy and safety profiles [11]. 2) It constrains our exploration of causes of morbidity in patients with airway diseases whose clinical phenotype is not easily classified. 3) It jeopardises drug development for specific endotypes [4, 11, 47]. 4) It limits the generalisability of the results of most randomised controlled trials, since smokers are routinely excluded from asthma trials whereas COPD patients with reversible airflow limitation (or not exposed to smoking) have been historically excluded from most COPD trials $[1,4]$. These limitations are particularly important after the recent observation that different lung function trajectories through life can lead to "COPD" in adulthood [46].

In summary, the current "Oslerian diagnostic label" approach to airway diseases: 1) fails to provide optimal care in a significant number of patients because it does not consider the biological complexity of airway diseases and does not consider the distinct endotypes present in each patient $[1,11,48]$; 2) does not appreciate common patterns of disease (e.g. chronic cough) [49]; 3) can increase clinical practice variability [50] and enhance inappropriate prescription of some drugs (e.g. inhaled corticosteroids) in some patients [51]; 4) can contribute to treatment failure and high rates of hospital readmissions [50]; and, finally, 5) inhibits research progress [4].

\section{Treatable traits: a label-free, precision medicine approach to the diagnosis and management of chronic airway diseases}

We propose here a precision medicine strategy for the management of patients with airway disease that is "label-free" and based on the identification of "treatable traits" in each patient [52]. These traits can be "treatable" based on "phenotypic" recognition (and thereby probabilistic evidence based on positive and negative predictive values) or on deep understanding of the critical causal pathways (e.g. true "endotypes"). For the patient this distinction does not really matter, but for medical science it does. The concept of phenotypic characterisation of patients is not novel. In 1959, during the CIBA Guest Symposium, N. G. M. Orie and K de Vries had already promoted the use of so-called "defining criteria" as opposed to traditional diagnostic labels $[53,54]$. As discussed below, our proposal extends this concept by including new and better markers of airway disease in light of novel available targeted interventions.

By recognising the clinical and biological complexity of airway disease, it builds upon the current rigid diagnostic label approach (i.e. it can be applied in any patient with airway disease) and paves the way towards a more precise (and hopefully more effective and safe) therapy in these patients since it is aligned with causal mechanistic disease pathways $[17,52]$. Needless to say, it can have significant implications for the organisation of the healthcare system [4] and, hopefully, it may facilitate the development of new 
drugs by the pharmaceutical industry [47]. It is important to note that we have deliberately excluded children from this proposal because of the inherent specific characteristics of this patient population, although some of the same principles may still apply. We have focused on clinically stable patients because we consider that episodes of exacerbations of airway diseases are not treatable traits themselves, but the consequence of a given endotype(s), which should be the real therapeutic target $[11,48]$ in order to prevent their occurrence.

As shown in figure 1, the first question we propose the clinician should consider when attending an adult with symptoms, signs or events suggestive of airway disease is: is this "really" airway disease"? To answer this question we propose to routinely: 1) assess the clinical history and the presence of risk factors of airway diseases (smoking, allergies, occupation, family history, respiratory disease in early life), and then 2) measure spirometry, exhaled nitric oxide fraction ( $F \mathrm{eNO})$ and blood eosinophils.

This combined assessment determines the probability (High/Low) of airway disease being present. If there is a high probability that this patient suffers from airway disease, the next step we propose is to use a precision medicine approach to investigate what endotypes are driving airway disease in this particular patient and treat them accordingly. The therapy of the patient with airway disease is therefore based upon the treatable traits present which, importantly, are not mutually exclusive (tables 1-3). However, if there is an atypical history, no risk factors and normal test results, it is unlikely that the patient has airway disease and other alternative diagnosis should be considered (e.g. cardiovascular, psychological or skeletal diseases) (figure 1, and tables 2 and 3).

Needless to say, the list of treatable traits included in tables 1-3 reflects our own personal view of current knowledge (and hence is potentially biased), and we recognise that the level of evidence for involvement and recognisability of individual traits differs. These traits should therefore be only viewed as a first step in this debate $[62,63]$. However, there is evidence that focusing on treatable traits in a multidimensional management plan leads to highly significant improvements in quality of life [60]. In addition, this approach may allow engagement of the patient in the goals of a treatment plan [64].

Other potential strengths of this proposal are worth mentioning here. 1) Since it is a "label-free" approach, it does not start on the assumption that the diagnosis (asthma or COPD) is well established and clear, a situation which is not the case in many instances in clinical practice, particularly in primary care. This is a fundamental, but often overlooked, issue in the current guideline-directed management of airway diseases $[8,9]$. 2) The treatable trait approach is adaptable to all levels of care. For example, some traits should be regarded as sufficiently recognisable and important to be a primary focus of assessments at all levels of

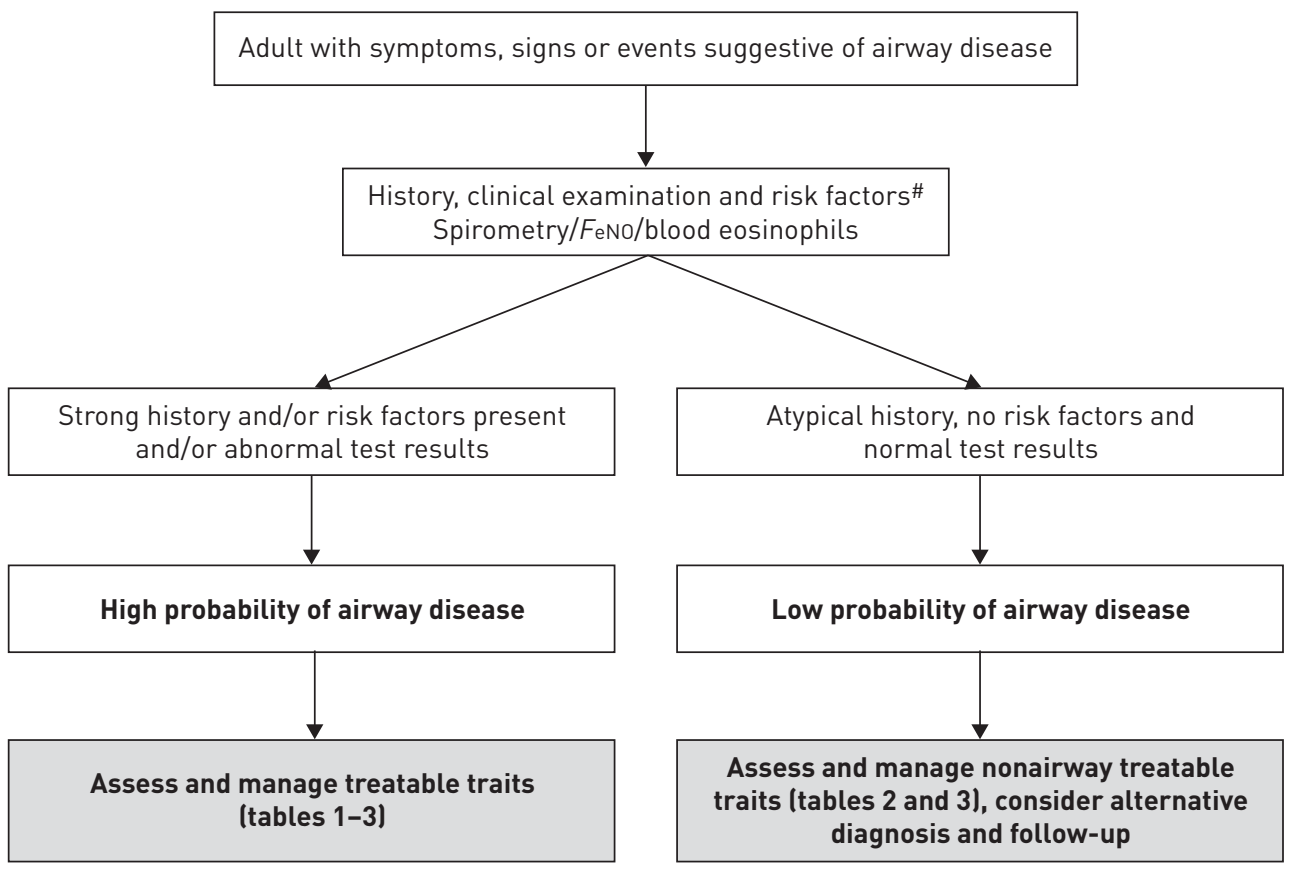

FIGURE 1 Proposed diagnostic strategy for an adult with symptoms, signs or events suggestive of airway disease. For further explanations, see text. FeNO: exhaled nitric oxide fraction. " : smoking, allergies, sputum production, occupation, lung development and growth. 
TABLE 1 Pulmonary treatable traits of airway diseases

\begin{tabular}{|c|c|c|c|c|c|c|c|}
\hline \multirow{2}{*}{$\begin{array}{l}\text { Treatable traits } \\
\text { (can coexist) }\end{array}$} & \multirow[t]{2}{*}{ Imp. } & \multirow[t]{2}{*}{ Rec. } & \multirow[t]{2}{*}{ Diagnostic criteria } & \multicolumn{3}{|c|}{ Treatment } & \multirow{2}{*}{$\begin{array}{l}\text { Main } \\
\text { expected } \\
\text { benefit }\end{array}$} \\
\hline & & & & First choice & Efficacy & Second choice & \\
\hline Airflow limitation [9] & +++ & +++ & $\begin{array}{c}\mathrm{FEV}_{1} / \mathrm{FVC}<0.7 \text { (or lower limit } \\
\text { of normal) }\end{array}$ & & & & S \\
\hline Airway smooth muscle contraction & ++ & +++ & $\begin{array}{l}\text { Bronchodilator reversibility, } \\
\text { peak expiratory flow variability, } \\
\text { positive } \mathrm{PC}_{20}\end{array}$ & $\begin{array}{l}\text { Maintenance: long-acting } \beta_{2} \text {-adrenergic } \\
\text { agonists/muscarinic antagonists; } \\
\text { rescue: short-acting } \beta_{2} \text {-adrenergic } \\
\text { agonists/muscarinic antagonists }\end{array}$ & +++ & $\begin{array}{l}\text { Inhaled corticosteroids, bronchial } \\
\text { thermoplasty" }\end{array}$ & s \\
\hline Loss of elastic recoil (emphysema) & +++ & ++ & $\begin{array}{l}\text { Chest computed tomography, } \\
\text { DLco, compliance }\end{array}$ & Smoking cessation & + & $\begin{array}{l}\text { Lung volume reduction surgery, } \\
\text { lung transplantation, } \\
\alpha_{1} \text {-anti-trypsin replacement if } \\
\text { deficient, valves, coils }\end{array}$ & S, P \\
\hline Airway mucosal oedema & ++ & + & $\begin{array}{l}\text { Chest computed tomography, } \\
\text { spirometry-induced } \\
\text { bronchoconstriction }\end{array}$ & Inhaled corticosteroids & ++ & $\begin{array}{l}\text { Oral corticosteroids, } \\
\text { anti-interleukin-5, -13,-4 }\end{array}$ & E \\
\hline Eosinophilic airway inflammation $[55,56]$ & +++ & +++ & $\begin{array}{l}\text { Sputum eosinophils, blood } \\
\text { eosinophils, FeNO, (periostin) }\end{array}$ & Inhaled corticosteroids & +++ & $\begin{array}{l}\text { Oral corticosteroids, leukotriene } \\
\text { receptor antagonists, anti-IgE, } \\
\text { anti-interleukin-5, }-13,-4\end{array}$ & E \\
\hline Chronic bronchitis & ++ & +++ & $\begin{array}{l}\text { Cough and sputum } \\
3 \text { months } \times 2 \text { years (no } \\
\text { eosinophilic airway } \\
\text { inflammation) }\end{array}$ & Smoking cessation & + & $\begin{array}{l}\text { Carbocysteine, macrolides, } \\
\text { roflumilast }\end{array}$ & $\mathrm{E}$ \\
\hline Airway bacterial colonisation ${ }^{\#}$ & ++ & ++ & $\begin{array}{l}\text { Sputum culture, } \\
\text { quantitative PCR }\end{array}$ & Antibiotics & ++ & $\begin{array}{l}\text { Long-term low-dose macrolides, } \\
\text { vaccination }\end{array}$ & $\mathrm{E} / \mathrm{S}$ \\
\hline Bronchiectasis"\# & ++ & ++ & Chest computed tomography & Drainage & + & $\begin{array}{l}\text { Macrolides, nebulised antibiotics, } \\
\text { surgery, vaccination }\end{array}$ & $E / S$ \\
\hline Cough reflex hypersensitivity $[49,57]$ & ++ & +++ & $\begin{array}{l}\text { Capsaicin challenge, cough } \\
\text { counts, cough questionnaire }\end{array}$ & $\begin{array}{l}\text { Speech and language } \\
\text { treatment [58] }\end{array}$ & + & Gabapentin [56] & S \\
\hline Pre-capillary pulmonary hypertension ${ }^{\#}$ & ++ & ++ & $\begin{array}{c}\text { Doppler echocardiography, } \\
\text { brain natriuretic peptide, right } \\
\text { heart catheterisation }\end{array}$ & $\begin{array}{l}\text { Long-term (domiciliary) } \\
\text { oxygen therapy }\end{array}$ & ++ & $\begin{array}{l}\text { Noninvasive ventilation, } \\
\text { lung transplantation }\end{array}$ & $S, E, P$ \\
\hline \multicolumn{8}{|l|}{ Chronic respiratory failure ${ }^{\#}$} \\
\hline Arterial hypoxaemia & +++ & +++ & $\mathrm{PaO}_{2}<55 \mathrm{mmHg}$ & $\begin{array}{l}\text { Long-term (domiciliaryl } \\
\text { oxygen therapy }\end{array}$ & ++ & & $P$ \\
\hline Arterial hypercapnia & +++ & +++ & $\mathrm{PaCO}_{2}>45 \mathrm{mmHg}$ & & + & $\begin{array}{l}\text { Noninvasive ventilation, lung } \\
\text { transplantation }\end{array}$ & \\
\hline
\end{tabular}

Imp.: importance; Rec.: recognisability. Diagnostic criteria and treatments options in italics should be considered as experimental (under current investigation) or having an unfavourable risk-benefit ratio. Expected treatment benefits on: E: exacerbations (rate/severity); S: symptoms; P: prognosis. FEV1: forced expiratory volume in $1 \mathrm{~s}$; FVC: forced vital capacity; PC20: provocative concentration causing a $20 \%$ fall in $\mathrm{FEV}_{1} ; \mathrm{DLCO}$ : diffusing capacity of the lung for carbon monoxide; FeNO: exhaled nitric oxide fraction; $P_{\mathrm{aO}}$ : arterial oxygen tension; $\mathrm{PaCO}_{2}$ : arterial carbon dioxide tension. ${ }^{\#}$ : treatable traits probably best dealt with in a specialist setting; " ${ }^{\text {? }}$ not studied in COPD-like airway disease. 
TABLE 2 Extrapulmonary treatable traits of airway diseases

\begin{tabular}{|c|c|c|c|c|c|c|c|}
\hline \multirow{2}{*}{$\begin{array}{l}\text { Treatable traits } \\
\text { (can coexist) }\end{array}$} & \multirow[t]{2}{*}{ Imp. } & \multirow[t]{2}{*}{ Rec. } & \multirow[t]{2}{*}{ Diagnostic criteria } & \multicolumn{3}{|c|}{ Treatment } & \multirow{2}{*}{$\begin{array}{c}\text { Main } \\
\text { expected } \\
\text { benefit }\end{array}$} \\
\hline & & & & First choice & Efficacy & Second choice & \\
\hline Obesity & + & +++ & Body mass index & Diet, physical activity & + & $\begin{array}{c}\text { Medication, bariatric } \\
\text { surgery }\end{array}$ & $\mathrm{S}, \mathrm{P}$ \\
\hline Cachexia & + & +++ & Body mass index & Diet, physical activity & + & & $S, E$ \\
\hline $\begin{array}{l}\text { Obstructive sleep apnoea } \\
\text { syndrome }\end{array}$ & + & ++ & $\begin{array}{l}\text { Questionnaires, } \\
\text { polysomnography }\end{array}$ & $\begin{array}{c}\text { Continuous positive airway } \\
\text { pressure }\end{array}$ & + & $\begin{array}{c}\text { Weight loss, } \\
\text { mandibular } \\
\text { advancement splint }\end{array}$ & S, P \\
\hline Cardiovascular disease & ++ & +++ & $\begin{array}{l}\text { Electrocardiogram, } \\
\text { Doppler } \\
\text { echocardiography, brain } \\
\text { natriuretic peptide }\end{array}$ & $\begin{array}{l}\text { Angiotensin-converting } \\
\text { enzyme inhibitors, } \\
\text { diuretics, } \beta \text {-blockers }\end{array}$ & ++ & Surgery & $S, E, P$ \\
\hline $\begin{array}{l}\text { Gastro-oesophageal reflux } \\
\text { disease [59] }\end{array}$ & + & ++ & $\begin{array}{l}\text { Gastrointestinal } \\
\text { endoscopy, pH } \\
\text { monitoring }\end{array}$ & $\begin{array}{c}\text { Proton pump inhibitors, } \mathrm{H}_{2} \\
\text { antagonist }\end{array}$ & + & Surgery & $\mathrm{S}$ \\
\hline $\begin{array}{l}\text { Upper airway diseases: } \\
\text { rhino-sinusitis }\end{array}$ & + & ++ & $\begin{array}{l}\text { History and examination, } \\
\text { imaging }\end{array}$ & Topical steroids & ++ & $\begin{array}{l}\text { Leukotriene receptor } \\
\text { antagonists, } \\
\text { antihistamines, } \\
\text { surgery }\end{array}$ & $S, E$ \\
\hline $\begin{array}{l}\text { Upper airway diseases: } \\
\text { inducible laryngeal } \\
\text { obstruction (vocal cord } \\
\text { dysfunction) }\end{array}$ & ++ & + & $\begin{array}{l}\text { Fibre optic laryngoscopy, } \\
\text { flow-volume curve, } \\
\text { dynamic neck computed } \\
\text { tomography }\end{array}$ & $\begin{array}{l}\text { Speech pathology } \\
\text { therapy [58] }\end{array}$ & ++ & $\begin{array}{l}\text { Laryngeal botulinum } \\
\text { toxin, psychology/ } \\
\text { psychiatry }\end{array}$ & $\mathrm{S}$ \\
\hline $\begin{array}{l}\text { Persistent systemic } \\
\text { inflammation }[60,61]\end{array}$ & ++ & ++ & $\begin{array}{l}\text { High-sensitivity } \\
\text { C-reactive protein }\end{array}$ & & $?$ & Statins & $S, E, P$ \\
\hline
\end{tabular}

Imp.: Importance; Rec.: recognisability. Diagnostic criteria and treatments options in italics should be considered as experimental lunder current investigation) or having an unfavourable risk-benefit ratio. Expected treatment benefits on: E: exacerbations (rate/severity); S: symptoms; P: prognosis.

care, whereas others may be more appropriately assessed and dealt with in specialist care (table 1). 3) This is the first time that specific diagnostic criteria for treatable traits have been proposed, and expected treatment benefits in terms of symptoms, risk of exacerbations and prognosis outlined (tables 1-3). 4) It is based on distinct pathophysiological processes or endotypes without making assumptions about links between different treatable traits. For instance, it dissociates airway hyperresponsiveness (an airway smooth muscle-related phenotype) from the type of airway inflammation present (eosinophilic or neutrophilic). 5) It may be cost-effective because of the expected larger therapeutic response. 6) It can stimulate best translational research by identifying knowledge gaps (tables 1-3). 7) It can help to identify key inclusion/ exclusion criteria for future randomised clinical trials.

\section{Potential limitations}

This proposal raises several questions and has a number of potential limitations that are discussed below. 
TABLE 3 Treatable behaviour/lifestyle risk factors of airway diseases

\begin{tabular}{|c|c|c|c|c|c|c|c|}
\hline $\begin{array}{l}\text { Treatable traits } \\
\text { (can coexist) }\end{array}$ & Imp. & Rec. & Diagnostic criteria & \multicolumn{3}{|c|}{ Treatment } & $\begin{array}{c}\text { Main } \\
\text { expected } \\
\text { benefit }\end{array}$ \\
\hline $\begin{array}{l}\text { Exposure to sensitising } \\
\text { agents/pollution }\end{array}$ & ++ & ++ & $\begin{array}{l}\text { Radio allergen } \\
\text { absorbance test, } \\
\text { skin-prick testing }\end{array}$ & Avoidance, desensitisation & + & $\begin{array}{l}\text { Air filtration } \\
\text { systems }\end{array}$ & $S, E$ \\
\hline Symptom perception & ++ & + & $\begin{array}{l}\text { Mismatch between } \\
\text { subjective and } \\
\text { objective findings }\end{array}$ & $\begin{array}{l}\text { Reassurance, breathing } \\
\text { exercises }\end{array}$ & ++ & & $\mathrm{S}$ \\
\hline $\begin{array}{l}\text { Side-effects of other } \\
\text { treatments }\end{array}$ & + & ++ & Monitored withdrawal & Treatment optimisation & + & Change device & $\mathrm{S}$ \\
\hline Adherence to treatment & +++ & ++ & $\begin{array}{l}\text { Prescription refill rate, } \\
\text { chipped inhalers }\end{array}$ & $\begin{array}{c}\text { Education, self-management } \\
\text { support }\end{array}$ & + & & $S, E$ \\
\hline $\begin{array}{l}\text { Poor inhalation } \\
\text { technique }\end{array}$ & ++ & ++ & $\begin{array}{l}\text { Observation, training } \\
\text { devices }\end{array}$ & Education & + & & $S, E$ \\
\hline $\begin{array}{l}\text { Family and social } \\
\text { support }\end{array}$ & ++ & ++ & & Family therapy & + & & $S, E$ \\
\hline $\begin{array}{l}\text { Imp.: importance; Rec.: } \\
\text { current investigation) or } \\
\text { S: symptoms; P: prognosi }\end{array}$ & $\begin{array}{l}\text { ognis } \\
\text { laving }\end{array}$ & ability & $\begin{array}{l}\text { Diagnostic criteria and } \\
\text { nfavourable risk-benefit }\end{array}$ & $\begin{array}{l}\text { eatments options in italics s } \\
\text { atio. Expected treatment b }\end{array}$ & $\begin{array}{l}\text { Id be } c \\
\text { fits on: }\end{array}$ & $\begin{array}{l}\text { sidered as expe } \\
\text { E: exacerbations }\end{array}$ & $\begin{array}{l}\text { ntal lund } \\
\text { te/severit }\end{array}$ \\
\hline
\end{tabular}

Should the terms "asthma" and "COPD" be abandoned?

The proposal outlined in this Perspective, i.e. to manage patients with airway disease based on those treatable traits present in each individual and to abandon the traditional diagnostic labels, is a paradigm change. We are firmly convinced that it better reflects the clinical and biological complexity of airway diseases, and may eventually result in better patient management than the current "label-based" approach. However, we also acknowledge that it is only partially based on evidence, e.g. treatment guided by sputum eosinophils (a phenotype traditionally related to "asthma") improves clinical outcomes in smokers with fixed airflow limitation (labelled as "COPD") [65]. Hence, before our proposal can be fully implemented in clinical practice, it requires time to generate experimentally the scientific evidence that supports it (or not), as discussed below. In the meantime, we propose that the concept of treatable traits in airway disease should "complement and refine" the diagnostic labels of asthma and COPD (as used in the respective GINA (Global Initiative for Asthma) and GOLD (Global Initiative for Obstructive Lung Disease) reports). Using the treatable trait approach proposed here, there will be patients with absolutely classical asthma, i.e. eosinophilic airway disease with bronchial hyperresponsiveness and complete reversibility of the airflow limitation, who would be characterised as such according to this new paradigm, likewise COPD patients with irreversible airflow limitation and chronic neutrophilic airway disease. However, many patients will incompletely fit these two extreme patterns or will have additional complicating factors. In these patients, a wider and more precise assessment may enable treatment to be better targeted. Thus, until the required evidence is fully available to completely eliminate the old labels (asthma and COPD), we would have to continue using them, but now with added terms (e.g. "Severe asthma, with a degree of fixed airflow limitation likely due to smoking, high risk of exacerbations, absence of eosinophilia, but high expression of XX", provided that XX is "treatable"!) [66].

How can this proposal be further developed and/or validated?

Several initiatives can facilitate the refinement and eventual validation (or disproval) of this proposal. First, this document should be understood as a first step that only aims to generate debate across the academic community, pharmaceutical industry, guideline committees, regulatory agencies, patients and other 
potentially interested stakeholders. The organisation of a multidisciplinary workshop is a conceivable and likely needed initiative to facilitate this discussion. Second, following this discussion, rigorously designed research projects need to test the feasibility and validity of this proposal. Potential study goals may include, among others: 1) the evaluation of the feasibility of the algorithm depicted in figure 1 in a pilot study in primary care; 2) the comparison of the efficacy/safety of this management strategy versus currently recommended strategies, both in primary and specialised care domains; 3) the assessment of its cost-effectiveness (e.g. potential reduction of inhaled corticosteroid use in COPD); 4) testing if a treatable trait-based strategy is equally effective in different groups of patients and healthcare systems; 5) development and testing of effective implementation strategies for managing treatable traits; and 6) patient acceptance of the treatable trait model of care. These are complex and expensive studies that require the participation of different stakeholders. The establishment of a public-private consortium may be a viable alternative [4].

\section{Is this strategy feasible in primary care?}

Precision medicine approaches are starting to show benefits in well-characterised patients with severe disease $[2,3,42,67]$, but are conceptually valid and pragmatically viable in milder patients attended in primary care, providing the recommended assessments are simple enough, a clear and practicable message is given, and the necessary training, encouragement and resources are provided. Experience shows that primary-care practitioners are fully capable of encompassing change. For example, over the last few decades, the ways they diagnose, assess and treat common conditions such as heart failure, hypertension and diabetes have changed radically. It is now routine to use biomarkers such as brain natriuretic peptide and echocardiography to diagnose, risk stratify and direct treatment for heart failure, a condition that used to be diagnosed with a stethoscope and treated empirically with diuretics. Along these lines, the UK NICE (National Institute for Health and Care Excellence) guideline on asthma diagnosis and monitoring has recommended that spirometry (with reversibility testing when obstruction is shown) and FeNO are measured routinely for all individuals with suspected asthma based on health economic modelling showing that this is the most clinically effective and cost-effective strategy [68]. We believe therefore that our proposal (figure 1) is feasible in primary care, although referral to specialised care will be needed in complex patients.

\section{Registration authorities, pharmaceutical companies and guideline committees}

This proposal may be difficult to accept by registration authorities for whom the traditional terms "asthma" and "COPD" are easier to understand. However, this simplification can be dangerous. For example, the use of "Oslerian diagnostic labels" without further investigating the underlying endotype(s) has resulted in most individuals with airway disease being excluded from the major randomised clinical trials [69] which, eventually, are incorporated into documents that guide their treatment $[9,12]$. Moreover, the clinically important beneficial effects of biological agents targeting eosinophilic airway inflammation were very nearly missed for similar reasons [35-38]. However, things are changing. For example, the US Food and Drug Administration has managed very well in dealing with similar issues in cancer [70], and companies can and do register a treatment/biomarker combination ("companion diagnostic") for an increasing number of pathway-specific treatments for cancer subtypes [71-74]. Our proposal may also be problematic for pharmaceutical companies, since it immediately cuts their market size if they only use the drug in a subset of the disease of interest $[4,75]$. Finally, guideline committees might eventually have to adapt their documents on the basis of a properly validated treatable traits approach to airway diseases.

\section{Conclusions}

The classic Oslerian classification of human diseases has proven very successful in a large proportion of patients with asthma or COPD, and the GINA and GOLD documents have been of enormous value to improve the diagnosis and treatment of many patients around the globe. However, airway diseases are complex and often overlap. Thus, in order to continue improving the management and prognosis of these patients, new biological knowledge needs to be incorporated into their clinical management. Systems approaches will be key in order to develop a comprehensive understanding of the biological mechanisms (i.e. endotypes) that underlie the clinical manifestation(s) of airway diseases (i.e. phenotypes) [4, 5, 76]. We propose here a strategy based on the presence of, nonmutually exclusive, treatable traits that may contribute to move the field towards precision medicine of airway diseases.

\section{Acknowledgements}

The authors thank Novartis for supporting a meeting in Zurich (January 2015) that triggered the discussions that fuelled this Perspective; Novartis did not have any input in the final content.

\section{References}

1 Vanfleteren LEGW, Kocks JWH, Stone IS, et al. Moving from the Oslerian paradigm to the post-genomic era: are asthma and COPD outdated terms? Thorax 2014; 69: 72-79. 
Collins FS, Varmus H. A new initiative on precision medicine. N Engl J Med 2015; 372: 793-795.

3 Jameson JL, Longo DL. Precision medicine - personalized, problematic, and promising. N Engl J Med 2015; 372: 2229-2234.

4 Agusti A, Anto JM, Auffray C, et al. Personalized respiratory medicine: exploring the horizon, addressing the issues. Am J Respir Crit Care Med 2015; 191: 391-401.

5 Agusti A, Sobradillo P, Celli B. Addressing the complexity of chronic obstructive pulmonary disease: from phenotypes and biomarkers to scale-free networks, systems biology, and P4 medicine. Am J Respir Crit Care Med 2011; 183: 1129-1137.

6 Barabasi AL, Gulbahce N, Loscalzo J. Network medicine: a network-based approach to human disease. Nat Rev Genet 2011; 12: 56-68.

7 Diez D, Agusti A, Wheelock CE. Network analysis in the investigation of chronic respiratory diseases: from basics to application. Am J Respir Crit Care Med 2014; 190: 981-988.

8 Reddel HK, Bateman ED, Becker A, et al. A summary of the new GINA strategy: a roadmap to asthma control. Eur Respir J 2015; 46: 622-639.

9 Vestbo J, Hurd SS, Agusti A, et al. Global strategy for the diagnosis, management and prevention of chronic obstructive pulmonary disease, GOLD Executive Summary. Am J Respir Crit Care Med 2013; 187: 347-365.

10 Global Strategy for Asthma Management and Prevention. Global strategy for the diagnosis management and prevention of chronic obstructive pulmonary disease. Asthma, COPD and asthma-COPD overlap syndrome (ACOS). 2014. http://www.goldcopd.org/uploads/users/files/AsthmaCOPDOverlap.pdf Date last accessed: December 1, 2015.

11 Woodruff PG, Agusti A, Roche N, et al. Current concepts in targeting chronic obstructive pulmonary disease pharmacotherapy: making progress towards personalised management. Lancet 2015; 385: 1789-1798.

12 Bateman ED, Reddel HK, van Zyl-Smit RN, et al. The asthma-COPD overlap syndrome: a staging post to a revised taxonomy of chronic airways diseases? Lancet Respir Med 2015; 3: 719-728.

13 Snyder LJ. Eye of the beholder: Johannes Vermeer, Antoni van Leeuwenhoek, and the reinvention of seeing. 1 Edn. New York, Norton, 2015.

14 Anderson GP. Endotyping asthma: new insights into key pathogenic mechanisms in a complex, heterogeneous disease. Lancet 2008; 372: 1107-1119.

15 Orie NG, Sluiter HJ, De Vries K, et al. The host factor in bronchitis. In: Orie NG, Sluiter HJ, eds. Bronchitis. Assen, Royal Vangorcumd, 1961; pp. 43-59.

16 Orie NG, Slutter HJ, De Vries K, et al. [Chronic nonspecific respiratory diseases]. Ned Tijdschr Geneeskd 1961; 105: 2136-2139.

17 Agusti A. The path to personalized medicine in COPD. Thorax 2014; 69: 857-864.

18 Agusti A, MacNee W. The COPD control panel: towards personalised medicine in COPD. Thorax 2013; 68: 687-690.

19 Martinez FD, Vercelli D. Asthma. Lancet 2013; 382: 1360-1372.

20 Demoly P, Gueron B, Annunziata K, et al. Update on asthma control in five European countries: results of a 2008 survey. Eur Respir Rev 2010; 19: 150-157.

21 Turner S, Thomas M, von Zeigenweidt J, et al. Prescribing trends in asthma: a longitudinal observational study. Arch Dis Child 2009; 94: 16-22.

22 Pavord ID, Shaw DE, Gibson PG, et al. Inflammometry to assess airway diseases. Lancet 2008; 372 : $1017-1019$.

23 Smith AD, Cowan JO, Brassett KP, et al. Exhaled nitric oxide: a predictor of steroid response. Am J Respir Crit Care Med 2005; 172: 453-459.

24 Malinovschi A, Fonseca JA, Jacinto T, et al. Exhaled nitric oxide levels and blood eosinophil counts independently associate with wheeze and asthma events in National Health and Nutrition Examination Survey subjects. $J$ Allergy Clin Immunol 2013; 132: 821-827.

25 Powell H, Murphy VE, Taylor DR, et al. Management of asthma in pregnancy guided by measurement of fraction of exhaled nitric oxide: a double-blind, randomised controlled trial. Lancet 2011; 378: 983-990.

26 Honkoop PJ, Loijmans RJ, Termeer EH, et al. Symptom- and fraction of exhaled nitric oxide-driven strategies for asthma control: a cluster-randomized trial in primary care. J Allergy Clin Immunol 2015; 135: 682-688.

27 Hanania NA, Wenzel S, Rosen K, et al. Exploring the effects of omalizumab in allergic asthma: an analysis of biomarkers in the EXTRA study. Am J Respir Crit Care Med 2013; 187: 804-811.

28 Pascoe S, Locantore N, Dransfield MT, et al. Blood eosinophil counts, exacerbations, and response to the addition of inhaled fluticasone furoate to vilanterol in patients with chronic obstructive pulmonary disease: a secondary analysis of data from two parallel randomised controlled trials. Lancet Respir Med 2015; 3: e27.

29 Buhl R, Soler M, Matz J, et al. Omalizumab provides long-term control in patients with moderate-to-severe allergic asthma. Eur Respir J 2002; 20: 73-78.

30 Ortega H, Li H, Suruki R, et al. Cluster analysis and characterization of response to mepolizumab: a step closer to personalized medicine for patients with severe asthma. Ann Am Thorac Soc 2014; 11: 1011-1017.

31 Brightling CE, Bleecker ER, Panettieri RA Jr, et al. Benralizumab for chronic obstructive pulmonary disease and sputum eosinophilia: a randomised, double-blind, placebo-controlled, phase 2a study. Lancet Respir Med 2014; 2: 891-901.

32 Laviolette M, Gossage DL, Gauvreau G, et al. Effects of benralizumab on airway eosinophils in asthmatic patients with sputum eosinophilia. J Allergy Clin Immunol 2013; 132: 1086-1096.

33 Bush A, Kleinert S, Pavord ID. The asthmas in 2015 and beyond: a Lancet Commission. Lancet 2015; 385: 1273-1275.

34 Barnes PJ, Bonini S, Seeger W, et al. Barriers to new drug development in respiratory disease. Eur Respir J 2015; 45: 1197-1207.

35 Haldar P, Brightling CE, Hargadon B, et al. Mepolizumab and exacerbations of refractory eosinophilic asthma. N Engl J Med 2009; 360: 973-984.

36 Nair P, Pizzichini MM, Kjarsgaard M, et al. Mepolizumab for prednisone-dependent asthma with sputum eosinophilia. N Engl J Med 2009; 360: 985-993.

37 Corren J, Lemanske RF, Hanania NA, et al. Lebrikizumab treatment in adults with asthma. N Engl J Med 2011; 365: 1088-1098.

38 Wenzel S, Ford L, Pearlman D, et al. Dupilumab in persistent asthma with elevated eosinophil levels. $N$ Engl $J$ Med 2013; 368: 2455-2466. 
39 Loscalzo J, Kohane I, Barabasi AL. Human disease classification in the postgenomic era: a complex systems approach to human pathobiology. Mol Syst Biol 2007; 3: 124.

40 Vermeire PA, Pride NB. A "splitting" look at chronic nonspecific lung disease (CNSLD): common features but diverse pathogenesis. Eur Respir J 1991; 4: 490-496.

41 Venter JC, Adams MD, Myers EW, et al. The sequence of the human genome. Science 2001; 291: 1304-1351.

42 Ritchie MD, de Andrade M, Kuivaniemi H. The foundation of precision medicine: integration of electronic health records with genomics through basic, clinical, and translational research. Front Genet 2015; 6: 104.

43 Fabbri LM, Romagnoli M, Corbetta L, et al. Differences in airway inflammation in patients with fixed airflow obstruction due to asthma or chronic obstructive pulmonary disease. Am J Respir Crit Care Med 2003; 167: 418-424.

44 DeMeo DL, Carey VJ, Chapman HA, et al. Familial aggregation of $\mathrm{FEF}_{25-75}$ and $\mathrm{FEF}_{25-75} / \mathrm{FVC}$ in families with severe, early onset COPD. Thorax 2004; 59: 396-400.

45 Tai A, Tran H, Roberts $\mathrm{M}$, et al. The association between childhood asthma and adult chronic obstructive pulmonary disease. Thorax 2014; 69: 805-810.

46 Lange P, Celli B, Agusti A, et al. Lung-function trajectories leading to chronic obstructive pulmonary disease. N Engl J Med 2015; 373: 111-122.

47 Holgate S, Agusti A, Strieter RM, et al. Drug development for airway diseases: looking forward. Nat Rev Drug Discov 2015; 14: 367-368.

48 Lotvall J, Akdis CA, Bacharier LB, et al. Asthma endotypes: a new approach to classification of disease entities within the asthma syndrome. J Allergy Clin Immunol 2011; 127: 355-360.

49 Morice AH, Millqvist E, Belvisi MG, et al. Expert opinion on the cough hypersensitivity syndrome in respiratory medicine. Eur Respir J 2014; 44: 1132-1148.

50 Lopez-Campos JL, Hartl S, Pozo-Rodriguez F, et al. Variability of hospital resources for acute care of COPD patients: the European COPD Audit. Eur Respir J 2014; 43: 754-762.

51 Agusti A, Fabbri LM. Inhaled steroids in COPD: when should they be used? Lancet Respir Med 2014; 2: 869-871.

52 Agusti A. Phenotypes and disease characterization in chronic obstructive pulmonary disease. Toward the extinction of phenotypes? Ann Am Thorac Soc 2013; 10: Suppl., S125-S130.

53 Flecther CM, Gilson JG, Hugh-Jones P, et al. Terminology, definitions and classifications of chronic pulmonary emphysema and related conditions. A report of the conclusions of a CIBA guest symposium. Thorax 1959; 14 286-299.

54 Sluiter HJ, Koeter GH, de Monchy JG, et al. The Dutch hypothesis (chronic non-specific lung disease) revisited Eur Respir J 1991; 4: 479-489.

55 Wagener AH, de Nijs SB, Lutter R, et al. External validation of blood eosinophils, FE $\mathrm{NO}_{\mathrm{N}}$ and serum periostin as surrogates for sputum eosinophils in asthma. Thorax 2015; 70: 115-120.

56 Zhang XY, Simpson JL, Powell H, et al. Full blood count parameters for the detection of asthma inflammatory phenotypes. Clin Exp Allergy 2014; 44: 1137-1145.

57 Ryan NM, Birring SS, Gibson PG. Gabapentin for refractory chronic cough: a randomised, double-blind, placebo-controlled trial. Lancet 2012; 380: 1583-1589.

58 Vertigan AE, Theodoros DG, Gibson PG, et al. Efficacy of speech pathology management for chronic cough: a randomised placebo controlled trial of treatment efficacy. Thorax 2006; 61: 1065-1069.

59 Hurst JR, Vestbo J, Anzueto A, et al. Susceptibility to exacerbation in chronic obstructive pulmonary disease. N Engl J Med 2010; 363: 1128-1138

60 McDonald VM, Higgins I, Wood LG, et al. Multidimensional assessment and tailored interventions for COPD: respiratory utopia or common sense? Thorax 2013; 68: 691-694.

61 Agusti A, Edwards LD, Rennard SI, et al. Persistent systemic inflammation is associated with poor clinical outcomes in COPD: a novel phenotype. PLoS One 2012; 7: e37483.

62 Gibson PG, McDonald VM, Marks GB. Asthma in older adults. Lancet 2010; 376: 803-813.

63 McDonald VM, Simpson JL, Higgins I, et al. Multidimensional assessment of older people with asthma and COPD: clinical management and health status. Age Ageing 2011; 40: 42-49.

64 McDonald VM, Higgins I, Simpson JL, et al. The importance of clinical management problems in older people with COPD and asthma: do patients and physicians agree? Prim Care Respir J 2011; 20: 389-395.

65 Siva R, Green RH, Brightling CE, et al. Eosinophilic airway inflammation and exacerbations of COPD: a randomised controlled trial. Eur Respir J 2007; 29: 906-913.

66 Chung KF, Wenzel SE, Brozek JL, et al. International ERS/ATS guidelines on definition, evaluation and treatment of severe asthma. Eur Respir J 2014; 43: 343-373.

67 Mirnezami R, Nicholson J, Darzi A. Preparing for precision medicine. N Engl J Med 2012; 366: 489-490.

68 National Institute for Health and Care Excellence (NICE). Asthma - diagnosis and monitoring. www.nice.org.uk/ guidance/indevelopment/gid-cgwave0640 Date last accessed: December 1, 2015.

69 Travers J, Marsh S, Williams M, et al. External validity of randomised controlled trials in asthma: to whom do the results of the trials apply? Thorax 2007; 62: 219-223.

70 US Food and Drug Administration. Guidances (drugs). http://www.fda.gov/Drugs/GuidanceComplianceRegulatoryInformation/Guidances/default.htm Date last accessed: December 1, 2015.

71 Akhmetov I, Ramaswamy R, Akhmetov I, et al. Market access advancements and challenges in "drug-companion diagnostic test" co-development in Europe. J Pers Med 2015; 5: 213-228.

72 Batrla R, Jordan BW. Personalized health care beyond oncology: new indications for immunoassay-based companion diagnostics. Ann N Y Acad Sci 2015; 1346: 71-80.

73 Jorgensen JT. Companion diagnostics: the key to personalized medicine. Foreword. Expert Rev Mol Diagn 2015; 15: $153-156$.

74 Caberlotto L, Lauria M. Systems biology meets -omic technologies: novel approaches to biomarker discovery and companion diagnostic development. Expert Rev Mol Diagn 2015; 15: 255-265.

75 Silverman EK, Loscalzo J. Developing new drug treatments in the era of network medicine. Clin Pharmacol Ther 2013; 93: 26-28.

76 Bousquet J, Anto J, Sterk P, et al. Systems medicine and integrated care to combat chronic noncommunicable diseases. Genome Med 2011; 3: 43-55. 